Article

\title{
A Natural Technology for Vacuum-Packaged Cooked Sausage Preservation with Potentially Postbiotic-Containing Preservative
}

\author{
Aloizio Lemos de Lima 1,2,*, Carlos Alberto Guerra ${ }^{3}$, Lucas Marques Costa ${ }^{3}$, Vanessa Sales de Oliveira ${ }^{1}$, \\ Wilson José Fernandes Lemos Junior ${ }^{4}$, Rosa Helena Luchese ${ }^{1}$ (D) and André Fioravante Guerra ${ }^{5, *(D)}$
}

1 Department of Food Technology, Federal Rural University of Rio de Janeiro, Seropédica 23897-970, Brazil; vanessasdo@bol.com.br (V.S.d.O.); rhluche@gmail.com (R.H.L.)

2 Instituto Federal do Rio de Janeiro (IFRJ), Pinheiral 27197-000, Brazil

3 BRC Ingredientes Ltda., Rio Claro 13505-600, Brazil; carlos@brcingredientes.com.br (C.A.G.); lucas@brcingredientes.com.br (L.M.C.)

4 Faculty of Science and Technology, Free University of Bolzano-Bozen, 39100 Bolzano, Italy; juniorjflemos@gmail.com

5 Departamento de Engenharia de Alimentos, Centro Federal de Educação Tecnológica Celso Suckow da Fonseca (CEFET/RJ), Valenca 27600-000, Brazil

* Correspondence: aloizio.lima@ifrrj.edu.br (A.L.d.L.); andre.guerra@cefet-rj.br (A.F.G.); Tel.: +55-21-98174-7619 (A.L.d.L.); +55-21-99142-3932 (A.F.G.)

check for updates

Citation: de Lima, A.L.; Guerra, C.A.; Costa, L.M.; de Oliveira, V.S.; Lemos Junior, W.J.F.; Luchese, R.H.; Guerra, A.F. A Natural Technology for Vacuum-Packaged Cooked Sausage Preservation with Potentially Postbiotic-Containing Preservative. Fermentation 2022, 8, 106. https://doi.org/10.3390/ fermentation 8030106

Academic Editor: Maurizio Ciani

Received: 31 January 2022

Accepted: 23 February 2022

Published: 28 February 2022

Publisher's Note: MDPI stays neutral with regard to jurisdictional claims in published maps and institutional affiliations.

Copyright: (c) 2022 by the authors. Licensee MDPI, Basel, Switzerland. This article is an open access article distributed under the terms and conditions of the Creative Commons Attribution (CC BY) license (https:// creativecommons.org/licenses/by/ $4.0 /)$.

\begin{abstract}
In this study, a potentially postbiotic-containing preservative (PPCP) was produced in an axenic fermentation system with Lacticaseibacillus paracasei DTA 83 as a natural technology alternative for vacuum-packaged cooked sausage preservation. Cooked sausage-related microorganisms were obtained during the induced spoiling process in packages by pair incubation of sausages at different temperatures. The turbidity method was used to determine the microbiota susceptibility to PPCP. A controlled in situ design was performed by adding PPCP on the surface or to the mass of the sausages. Sodium lactate FCC85, which was used according to the manufacturer's recommendation, was included in the design for comparison. The results revealed that PPCP was as efficient as FCC85, which indicates PPCP as a promising alternative to the use of natural technologies to preserve and develop functional cooked sausages. Moreover, a strategy to use preservatives in vacuum-packaged cooked sausages was presented: the concentration needed to achieve the total inhibition of the microbiota determined by an in vitro trial should be respected when adding PPCP on the sausages' surface. When adding PPCP to the mass of the sausages, the concentration that showed a partial inhibition in vitro can also be applied in situ.
\end{abstract}

Keywords: biocontrol; biocin; heat-inactivated microorganism; food safety; sustainability

\section{Introduction}

Lactic acid bacteria (LAB) constitute a heterogeneous group that has extensively reported on in the literature because of its potential benefits for consumer health [1,2]. Lacticaseibacillus paracasei DTA 83 has been described as a candidate strain to deliver probiotics in food matrices [3-5]. In contrast, since microorganisms may present invasive potential, studies have shown the administration of viable cells by healthy people as a subject of great concern. Thus, the use of postbiotics may be highlighted as a suitable alternative.

The presence of spoilage microorganisms in food represents a critical issue with repercussions on massive food waste and food loss worldwide [6]. The safety and stability of food may be affected by numerous factors, such as microbial presence and/or activity; biochemical, physical-chemical, and sensory alterations; nutritional losses; and others. When intrinsic and extrinsic aspects of food allow microbial growth, the microbial spoilage pathway becomes dominant $[7,8]$. 
Biopreservation is an alternative food preservation technology applied to replace artificial preservatives. The US Food and Drug Administration (FDA) recognizes both probiotics and their metabolites as Generally Recognized as Safe (G.R.A.S) (Section 2.1 CFR184). Thus, they are useful for controlling the development of pathogens and spoilage microorganisms in food and foodstuff. Moreover, FDA has determined that conditions for their use are prescribed in the referent regulations and are predicated on the use of nonpathogenic and nontoxicogenic strains of the respective organisms and on the use of current good manufacturing practice (184.1(b)). Despite all the advantages, the use of bacteriocins is still limited because of the high cost of their isolation and purification, mainly when considering their application in products of low cost. In this context, the use of precultured broth mediums by LAB, without bacteriocin isolation and purification, may be a promising strategy to prevent spoilage in meat products [9].

Heat-treated meat products, such as vacuum-packaged cooked sausages, are traditionally marketed at room temperature in Brazil, leading to food waste due to spoilage processes that may occur before the shelf life determined by the manufacturer [10]. The vacuum atmosphere selectively suppresses the growth of specific microbial groups, attributing the initial microbiota to anaerobic and facultative groups [11]. These microorganisms overgrow and produce metabolites that cause the rejection of the products by consumers [12]. As a solution, the food industry often increases the concentration of preservatives in meat products, which may result in abusive use.

Sodium lactate is a widespread commercial preservative commonly used in sausages to control microbial growth and increase shelf life [13]. However, the higher the concentration of sodium lactate added to a food product, the higher the content of sodium. Therefore, although sodium lactate is a safe preservative for food and foodstuff, its excessive intake may result in increased blood pressure for consumers [14]. Indeed, natural technologies to preserve food are of growing interest to food industries and consumers.

Metabolites produced by LAB have been extensively tested to biocontrol the growth of pathogenic and spoilage microorganisms in meat ecosystems [15-17]. L. paracasei DTA 83 is a strain of human origin of great functional and technological interest. It is a r-hemolytic and nonantibiotic resistant strain. Previous studies have demonstrated its potential to control the growth of Escherichia coli, Salmonella Typhimurium, Listeria innocua, and Candida albicans even after partial reduction in cell viability due to stress in the gastrointestinal transit. Technological features associated with the ability of L. paracasei DTA 83 to assimilate sugar in hardship conditions, such as brewer wort and plant extract solutions, were presented by Silva et al. and Oliveira et al. $[18,19]$. These aspects were decisive for selecting the strain for bioproduct processing. Moreover, maternal supplementation with L. paracasei DTA 83 reduced the expression of GAD 65, GAD 67, and GABAA receptor $\alpha 3$ subunit in the hippocampus, modulating Swiss mice offspring [4].

Thus, this study aimed to compare the efficacy of potentially postbiotic-containing preservative (PPCP) produced by an axenic fermentation system with $L$. paracasei DTA 83 and sodium lactate in extending the use-by date of vacuum-packaged cooked sausages. Moreover, a strategy based on the co-use of preservative and cold chain management was presented to retain the original properties of the sausages during the proposed shelf-life period of 90 days.

\section{Materials and Methods}

\subsection{Microbial Collection and Inoculum Preparation}

L. paracasei DTA 83 was isolated from newborns' stools at Rio de Janeiro (Brazil) in selective Lawvab agar medium as reported by Lemos Junior et al. [20]. The strain was genotypically identified by sequencing of the $16 \mathrm{~S}$ rDNA region and clustered by genetic similarity with other Lacticaseibacillus strains of the collection (Figure S1a) [21]. Furthermore, the complete genome data was deposited in GenBank under the accession number QRBH00000000 [22]. The strain has been classified as G.R.A.S. and characterized as a potential probiotic according to Tarrah et al. and Laureano-Melo et al. [3,4]. The technological 
features of the strain were assessed in food matrices by Silva et al. (Figure S1b) $[5,18]$. Additionally, it was described as a potential strain for delivering postbiotic compounds by Oliveira et al. [18].

L. paracasei DTA 83 cultures were thawed at $7^{\circ} \mathrm{C}$ for approximately $4 \mathrm{~h}$ and centrifuged at $6000 \times g$ for 5 min (2K15, Sigma Laborzentrifugen, Osterode am Harz, Germany) for pellet separation. The liquid fraction was discarded. Then, the remaining cell pellet was reconstituted with MRS broth and then incubated overnight at $36{ }^{\circ} \mathrm{C}$ for the microbial growth. To obtain sufficient biomass to produce PPCP on a pilot-industrial scale, the cultures were scaled up $1 / 10(\mathrm{vol} / \mathrm{vol})$ at $36^{\circ} \mathrm{C}$ in an axenic cultivation in a sterile MRS broth medium prepared with food-grade ingredients to obtain $30 \mathrm{~L}$ of inoculum.

\subsection{PPCP Production}

A stirred tank bioreactor of $300 \mathrm{~L}$, with automatic control of temperature and $\mathrm{pH}$, was used to produce PPCP in an axenic fermentation system with L. paracasei DTA 83. This part of the experiment was carried out at BRC Ingredientes Ltda., located in the city of Rio Claro, state of São Paulo, Brazil. Modified MRS broth was prepared with food-grade ingredients without the addition of polysorbate 80 (Tween 80). The heat treatment was performed in a tank (heating up of $1^{\circ} \mathrm{C}$ per minute) by the electrical activation of three resistors $(3 \mathrm{~kW})$. During heating, the medium was axially agitated at $84 \mathrm{rpm}$. The binomial $75{ }^{\circ} \mathrm{C}$ per $2 \mathrm{~h}$ was used to reduce the contaminants to an acceptable level (ca. $3 \log \mathrm{cfu} / \mathrm{g}$ ) and provide a competitive advantage to L. paracasei DTA 83 during the fermentation. After the heat treatment, the temperature of the medium was reduced to $36^{\circ} \mathrm{C}$ (heating down of $0.5^{\circ} \mathrm{C}$ per minute). L. paracasei DTA 83 biomass was produced in laboratory, scaling up $1 / 10(\mathrm{vol} / \mathrm{vol})$ of the culture into sterile modified MRS broth. A biological oxygen demand was used for incubation at $36^{\circ} \mathrm{C}$ to obtain $30 \mathrm{~L}$ of inoculum. A culture with $18 \mathrm{~h}$ of growth, comprehended into the growth $(\log )$ phase, was added (1/10 of inoculum) into the bioreactor containing $270 \mathrm{~L}$ of modified MRS medium to obtain a final inoculum concentration of ca. $7 \log \mathrm{cfu} / \mathrm{mL}$. After $72 \mathrm{~h}$ of fermentation coupled with a $\mathrm{pH}$ decay to around 3.5 , the medium was heat treated at $95^{\circ} \mathrm{C}$ for $5 \mathrm{~min}$ (heating up of $1^{\circ} \mathrm{C}$ per minute). PPCP was hot bottled in polypropylene containers of $10 \mathrm{~L}$. The presence of remaining cells of L. paracasei DTA 83 or contaminants was assessed by plate counting on MRS and plate count agar and potato dextrose agar acidified to $\mathrm{pH} 3.5$ with tartaric acid (all media from HiMedia, Mumbai, India).

\subsection{In Vitro Efficacy of PPCP}

Cooked sausage-related microorganisms were obtained from five packages of sausages, with collection at zero time $(n=1)$ and after pair incubation of samples at $7^{\circ} \mathrm{C}$ (collection on days 3 and 6) and $36^{\circ} \mathrm{C}$ (collection on days 2 and 4). A decimal suspension was prepared by weighing the sausages and adding $0.1 \%$ of peptone sterile water to the package. This step was conducted to count the microorganisms in the sausages, as well as those accumulated in the liquid inside the package after syneresis. After the samples were homogenized in a stomacher (SP-190, SPLabor, Brazil) for $90 \mathrm{~s}$ at 230 revolutions per minute (rpm), aliquots $(100 \mu \mathrm{L})$ was transferred to tubes with $5 \mathrm{~mL}$ of brain-heart infusion, Casoy, deMan, Rogosa, and Sharp, and yeast-peptone-dextrose extract. The tubes were incubated at $36{ }^{\circ} \mathrm{C}$ for $24-48 \mathrm{~h}$. The inoculum was obtained separately from each culture medium by transferring $1 \mathrm{~mL}$ of the tube content, with expressive growth (turbidity above 0.5 MacFarland standard), to an empty sterile screw-cap tube. Cells free of toxic compounds were obtained by twice washing the biomass cell pellets with a routine of centrifugation at $6000 \times g$ for $6 \mathrm{~min}$ for pellet sedimentation at the bottom of the tube, discarding the liquid fraction, adding $2 \mathrm{~mL}$ of phosphate buffer $\mathrm{pH} \mathrm{7.2,} \mathrm{and} \mathrm{homogenizing} \mathrm{in} \mathrm{vortex.} \mathrm{The} \mathrm{turbidity} \mathrm{of} \mathrm{the}$ microbial suspension was adjusted to $0.5 \mathrm{McFarland}$ standard and 2-fold diluted. PPCP was randomly outlined to final concentrations of $0.0,0.1,0.3,0.5,1.0,1.5,2.0,2.5,3.0$, and $3.5 \%(\mathrm{vol} / \mathrm{vol})$ in the brain-heart infusion broth. The dilutions were prepared in the same media used in the test to avoid a shortage of nutrients for microbial growth. Finally, 
$100 \mu \mathrm{L}$ of the microbial suspension was added into the tubes to achieve a final microbial concentration of ca. $5 \log \mathrm{cfu} / \mathrm{mL}$. A digital stirred water bath (SP-156/22, SPLabor, Brazil), with automatic temperature control, was used to incubate the tubes at $36{ }^{\circ} \mathrm{C}$ for $72 \mathrm{~h}$. The absorbance was read in a photometry device at $600 \mathrm{~nm}$ (Spectrum SP-2000UV /2000UVPC, Shanghai, China) for a regular $6 \mathrm{~h}$ period. Before reading, the tubes were vortexed, and the absorbance was directly measured in the tubes. A tube without inoculum was used as blank and for equipment calibration at each reading.

\subsection{In Situ Efficacy of PPCP}

PPCP was tested in situ at concentrations of 1.0, 2.0, and 3.0\% by adding the preservatives on the surface or to the mass of the sausages. The sausages were manufactured on an industrial-pilot scale for the meat industry located in Rio de Janeiro, Brazil. The production was performed according to the meat products' standard procedures, as follows: input of feed of raw materials, defrosting or breaking in frozen block crusher, grinding through industrial grinder knife (8-12 mm hole diameter $(\varnothing)$ plate) (PC 106, Canoas, Brazil), mixing and addition of food ingredients (lean meat, pork fat, spices, and food additives) (250L, Cataguases, Brazil), stuffing in 15 and $250 \mathrm{~mm}$ inner (diameter $\times$ length) natural pork casing (NDX 22 Viscofan, Spain), cooking to achieve $72{ }^{\circ} \mathrm{C}$ (approximately $2 \mathrm{~h}$ ) (MECA2G, Pará de Minas, Brazil) at the coldest point of the sausage, cooling by immersion in a cold water bath, and packing using a vacuum-package system with 5 to 7 pieces of sausage per package. PPCP was added to the mass of the sausages with other ingredients during the sausage mass preparation or directly into the packages to hurdle microbial growth after syneresis. The net weight of the sausages in the packages was used to calculate the volume of PPCP added into the packages. Sodium lactate FCC85 (Corbion, Purak, Brazil), added to the mass or on the sausages' surface, was included in the design to compare the efficacy of the PPCP with that of a reference widespread commercial preservative. The addition of sodium lactate was performed following the manufacturer's recommendation. Sausages without preservatives or with sterile deionized water, added to the mass or on the sausages' surface, were included as blank and control, respectively (Table 1). After manufacturing, the packages were immediately addressed to the laboratory.

Table 1. Formulation of pork sausage samples.

\begin{tabular}{|c|c|c|c|c|c|c|c|c|c|c|c|}
\hline \multirow[b]{3}{*}{ Ingredients (\%) } & \multicolumn{11}{|c|}{ Treatments } \\
\hline & \multicolumn{6}{|c|}{ Sausage Surface } & \multicolumn{5}{|c|}{ Sausage Mass } \\
\hline & Blank & $\begin{array}{c}\text { Control } \\
\text { (Water) } \\
2.0 \%\end{array}$ & $\begin{array}{c}\text { Sodium } \\
\text { Lactate } \\
2.0 \%\end{array}$ & $\begin{array}{c}\text { PPCP }^{3} \\
1.0 \%\end{array}$ & $\begin{array}{c}\text { PPCP } \\
2.0 \%\end{array}$ & $\begin{array}{c}\text { PPCP } \\
3.0 \%\end{array}$ & $\begin{array}{c}\text { Control } \\
\text { (Water) } \\
2.0 \%\end{array}$ & $\begin{array}{c}\text { Sodium } \\
\text { Lactate } \\
2.0 \%\end{array}$ & $\begin{array}{c}\text { PPCP } \\
1.0 \%\end{array}$ & $\begin{array}{c}\text { PPCP } \\
2.0 \%\end{array}$ & $\begin{array}{c}\text { PPCP } \\
3.0 \%\end{array}$ \\
\hline Lean pork meat & 67.33 & 67.33 & 67.33 & 67.33 & 67.33 & 67.33 & 67.33 & 67.33 & 67.33 & 67.33 & 67.33 \\
\hline Pork fat & 20.00 & 20.00 & 20.00 & 20.00 & 20.00 & 20.00 & 20.00 & 20.00 & 20.00 & 20.00 & 20.00 \\
\hline Drinking water & 10.00 & 10.00 & 10.00 & 10.00 & 10.00 & 10.00 & 8.00 & 8.00 & 9.00 & 8.00 & 7.00 \\
\hline Salt (sodium chloride) & 1.80 & 1.80 & 1.80 & 1.80 & 1.80 & 1.80 & 1.80 & 1.80 & 1.80 & 1.80 & 1.80 \\
\hline Seasoning ${ }^{1}$ & 0.30 & 0.30 & 0.30 & 0.30 & 0.30 & 0.30 & 0.30 & 0.30 & 0.30 & 0.30 & 0.30 \\
\hline Sodium trypoliphosphate & 0.32 & 0.32 & 0.32 & 0.32 & 0.32 & 0.32 & 0.32 & 0.32 & 0.32 & 0.32 & 0.32 \\
\hline Sodium erythorbate & 0.10 & 0.10 & 0.10 & 0.10 & 0.10 & 0.10 & 0.10 & 0.10 & 0.10 & 0.10 & 0.10 \\
\hline Curing salt ${ }^{2}$ & 0.15 & 0.15 & 0.15 & 0.15 & 0.15 & 0.15 & 0.15 & 0.15 & 0.15 & 0.15 & 0.15 \\
\hline Sterile deionized water & & 2.00 & & & & & 2.00 & & & & \\
\hline Sodium lactate FCC85 & & & 2.00 & & & & & 2.00 & & & \\
\hline PPCP & & & & 1.00 & 2.00 & 3.00 & & & 1.00 & 2.00 & 3.00 \\
\hline
\end{tabular}

${ }^{1}$ Garlic powder, onion powder, black pepper, nutmeg, laurel powder, and celery powder; ${ }^{2}$ sodium chloride $(90 \%)$, sodium nitrite $(6 \%)$, and sodium nitrate $(4 \%){ }^{3}$ potentially postbiotic-containing preservative.

\subsection{Sample Characterization}

\subsubsection{Physicochemical Analyses}

The analyses were carried out following the AOAC procedures [23]. Moisture content $(\% w / v)$ was determined by oven drying at $105{ }^{\circ} \mathrm{C}$ until constant weight. Ash content $(\% w / v)$ was determined by incinerating samples in a muffle furnace at $550{ }^{\circ} \mathrm{C}$ for $4 \mathrm{~h}$. 
Protein level $(\% w / v)$ was obtained by the Kjeldahl method. The Soxhlet extraction method with hexane was applied to determine the total fat content $(\% w / v)$. The total carbohydrate content was calculated as the difference between 100 and the sum of the percentages of moisture, ash, lipid, and protein. Total energy (kcal/100 g sample) was calculated according to the Atwater specific factor system $(4.27 \mathrm{kcal} / \mathrm{g}$ for protein or carbohydrate and $9.02 \mathrm{kcal} / \mathrm{g}$ for fat).

\subsubsection{Water Activity Measurement}

Changes in the electrical conductivity of an electrolyte, in accordance with the method ISO 18787 (2017) [24], were used for water activity measurement in a AcquaLab Lite device (Decagon, Washington, USA) provided with a dielectric humidity sensor and infrared sample surface temperature. Before measuring, the equipment was calibrated with two standard solutions $\left(\mathrm{K}_{2} \mathrm{SO}_{4}\right.$, aw 0.973 (CAS 7778-80-5) and $\mathrm{KCl}$, aw 0,843 (CAS 7447-40-7)) provided by the manufacturer. A maximum error of \pm 0.005 was considered as accuracy. To obtain a uniform sample, a piece of sausage was ground in an electric meat grinder (Centrífuga 1000, Britânia, Brazil). Excessive milling, which could lead to heating of samples and affect measurements, was avoided. Immediately after grinding, the sample portion was taken as quickly as possible to minimize exposure to humidity in the laboratory. A sample dish with a capacity of $7 \mathrm{~mL}$ was ${ }^{1} / 3$ filled with sample so that there was no empty space at the bottom. During the analytical series, the measurement stability was verified using standard solutions. A waiting time of approximately 15 min was established between each measurement after opening the equipment lid.

\subsection{3. $\mathrm{pH}$ Values}

Nondestructive measurement of $\mathrm{pH}$ was performed according to the method ISO 2917:1999(E) [25]. A portable meat pHmeter device (pH Classic, Akso, Brazil), equipped with a knife probe electrode (IP65, Akso, Brazil) and automatic compensation of temperature, was used. Sausages were randomly withdrawn from the packages, and the $\mathrm{pH}$ value was determined by direct sticking the electrode in 3 different positions of the sausage: the two ends and the central section of the pieces. Before measuring, the equipment was calibrated with buffer solutions, $\mathrm{pH} 4.00$ and $\mathrm{pH} 6.88$ at $20^{\circ} \mathrm{C}$. A maximum error of \pm 0.01 was considered as accuracy.

\subsection{Durability Study}

A predictive microbial method, named MicroLab_ShelfLife, was used to estimate the use-by date of vacuum-packaged cooked sausages at a chosen dynamic temperature profile (Figures S4 and S5 in Supplementary Material). The use-by dates for vacuum-packaged cooked sausages were established when spoilage microbial load achieved the maximum limit of ca. $9.3 \mathrm{log} \mathrm{cfu} / \mathrm{g}$. This is the borderline to determine when changes in sensory attributes related to the appearance of vacuum-packaged cooked sausages occur (Figures S2 and S3, Table S1). The horizontal method for enumeration of microorganisms (ISO 4833-1:2013) [26] was performed to determine the total microbial load, using plate count agar medium (HiMedia, Mumbai, India), at the zero time and after stimulating the microbial growth in the packages by pair incubation of samples at 7 and $36{ }^{\circ} \mathrm{C}$, with counts on days 3 and $6\left(7^{\circ} \mathrm{C}\right)$ and on days 2 and $4\left(36^{\circ} \mathrm{C}\right)$ of incubation (Figure S4). The number of colonies obtained at each dilution level was imputed in the MicroLab_ShelfLife computational package to determine the parameters of the microbial growth and to plot the predictive microbial growth curve (Figure S5).

A dynamic temperature profile was entered in the predictive model based on the measurements published by the AccuWeather forecast during 2021. Latitude and longitude coordinates ( $22^{\circ} 54^{\prime} 13^{\prime \prime}$ South; $43^{\circ} 12^{\prime} 35^{\prime \prime}$ West; Rio de Janeiro, Brazil) were considered as the climatic location, indicating the place where the sausages would be sold. According to the Köppen-Geiger classification, the climate of Rio de Janeiro is a tropical monsoon climate $(A m)$ [27]. The temperature data were grouped by season. The daily temperature 
profile, representing each climate season, was hourly grouped to fit in the MicroLab_ShelfLife platform (Figure 1). This profile was used to mimic the temperature during the product storage and disposal for sale in markets.

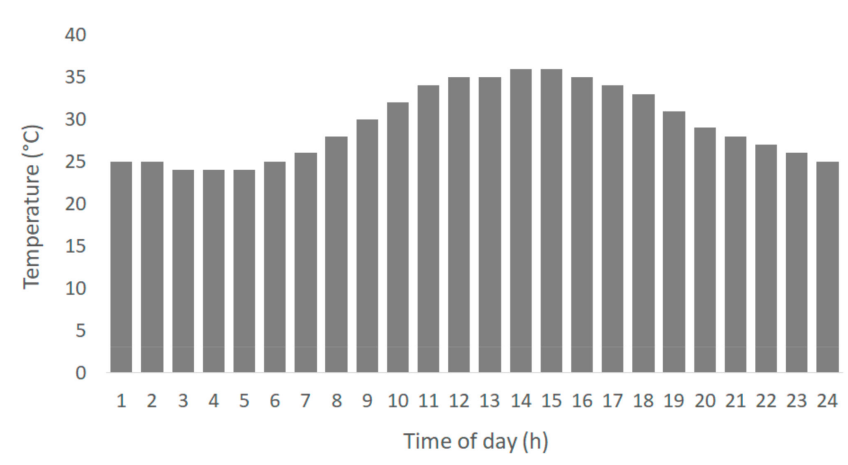

(a)

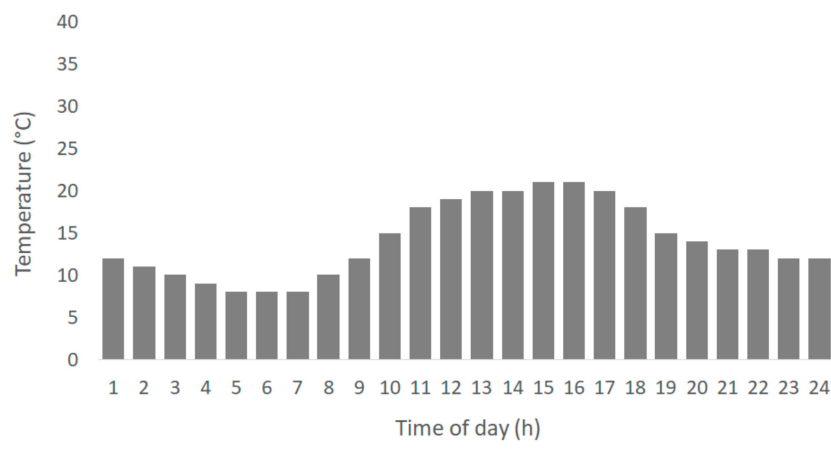

(c)

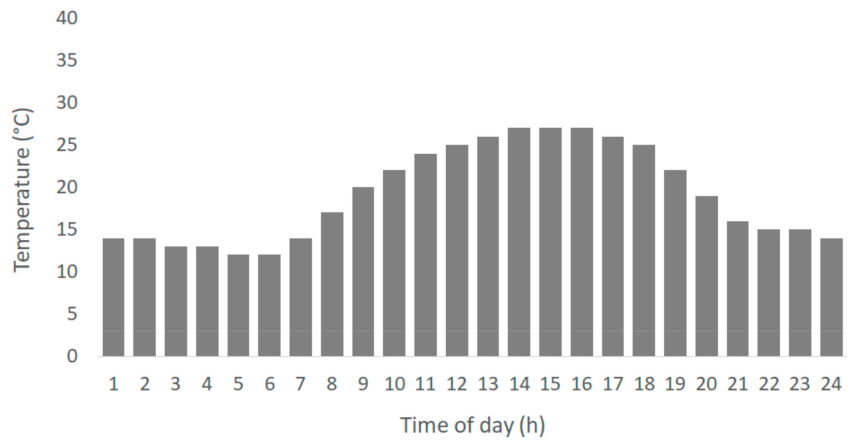

(b)

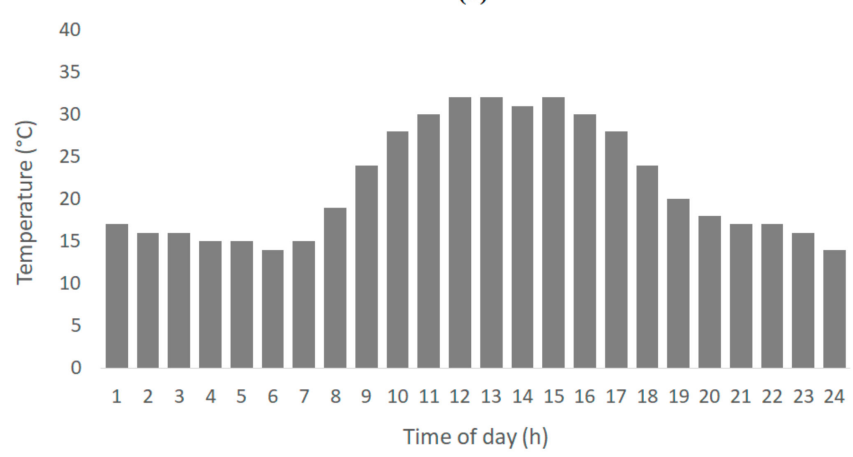

(d)

Figure 1. Temperature profile based on hourly variation during a one-day period to simulate the seasons: (a) summer, (b) autumn, (c) winter, (d) spring. They were determined based on the measurements published by AccuWeather (www.accuweather.com) for 2021. Latitude and longitude coordinates: $22^{\circ} 54^{\prime} 13^{\prime \prime}$ South; $43^{\circ} 12^{\prime} 35^{\prime \prime}$ West; Rio de Janeiro, Brazil, where a tropical monsoon climate $(A m)$ has been reported (Köppen-Geiger climatic classification) [27].

\subsection{Statistical Analyses}

Results related to PPCP efficacy against the growth of natural microbiota and physicochemical characterization of vacuum-packaged cooked sausages were obtained in triplicate. Linear regression was applied in the turbidity method regarding the incubation time with representative microbial growth, comprehended from 6 to $30 \mathrm{~h}$ of incubation at $36^{\circ} \mathrm{C}$, according to Equations (1)-(3). Angular coefficients from regressions (mean \pm standard error) were evaluated by analysis of variance (ANOVA) followed by Fisher's (LSD) test $(p<0.05)$ :

$$
\begin{gathered}
\dot{\mathrm{Y}} \pm \frac{\mathrm{t} \alpha}{2} \times \mathrm{SE} \times \sqrt{h i} \\
\dot{\mathrm{Y}} \pm \mathrm{t} \alpha / 2 \times \mathrm{SE} \times \sqrt{1+h i} \\
h i=1 / n+(x i-x)^{2} / \sum(x i-x)^{2}
\end{gathered}
$$

$\dot{Y}$ is the estimated value, $t \alpha / 2$ is the value of Student's t distribution, $n$ is the number of observations, $x i$ is the value of the sample, and $x$ is the mean.

A computational predictive modeling package,MicroLab_ShelfLife, was developed in the present study and used to predict the use-by date of vacuum-packaged cooked sausages from five packages of each sample group (Supplementary Material). The method was also used to evaluate the effect of the temperature associated with preservatives in the shelf life of the products and to estimate the initial microbial load of vacuum-packaged cooked sausages to achieve the proposed shelf-life period of 90 days. 


\section{Results}

In vitro trials revealed that PPCP addition at concentrations up to $0.5 \%$ did not inhibit microbial growth. In samples containing $1.0-3.0 \%$ of PPCP, microbial inhibition was partially achieved. Although the efficacy was directly proportional to the added concentration of PPCP, similar results were obtained by adding 1.0 or $1.5 \%$ of PPCP $(p>0.05)$. Total inhibition was achieved at concentrations above 3.0\% (Table 2, Figures 2 and 3).

Table 2. Linear regression parameters of microbial growth.

\begin{tabular}{|c|c|c|c|c|c|c|c|c|c|c|}
\hline \multirow[b]{2}{*}{ Coefficients } & \multicolumn{10}{|c|}{ (\%) of Potentially Postbiotic-Containing Preservative (PPCP) } \\
\hline & 0.0 & 0.1 & 0.3 & 0.5 & 1.0 & 1.5 & 2.0 & 2.5 & 3.0 & 3.5 \\
\hline$x i$ & $0.044^{\mathrm{a}}$ & $0.044^{\mathrm{a}}$ & $0.044^{\mathrm{a}}$ & $0.044^{\mathrm{a}}$ & $0.035^{\mathrm{a}}$ & $0.031^{\mathrm{a}}$ & $0.025^{\mathrm{b}}$ & $0.016^{\mathrm{c}}$ & $0.004^{\mathrm{d}}$ & $0.004^{\mathrm{d}}$ \\
\hline$y i$ & -0.299 & -0.294 & -0.298 & -0.305 & -0.309 & -0.281 & -0.242 & -0.137 & -0.018 & -0.034 \\
\hline$R^{2}$ & 0.978 & 0.981 & 0.979 & 0.977 & 0.959 & 0.955 & 0.921 & 0.961 & 0.881 & 0.088 \\
\hline SE & 0.111 & 0.109 & 0.110 & 0.111 & 0.088 & 0.079 & 0.065 & 0.040 & 0.012 & 0.011 \\
\hline SQ & 1890 & 1890 & 1890 & 1890 & 1890 & 1890 & 1890 & 1890 & 1890 & 1890 \\
\hline $\mathrm{n}$ & 18 & 18 & 18 & 18 & 18 & 18 & 18 & 18 & 18 & 18 \\
\hline $\mathrm{DF}(n-2)$ & 16 & 16 & 16 & 16 & 16 & 16 & 16 & 16 & 16 & 16 \\
\hline $\mathrm{t} \alpha / 2$ & 2.4729 & 2.4729 & 2.4729 & 2.4729 & 2.4729 & 2.4729 & 2.4729 & 2.4729 & 2.4729 & 2.4729 \\
\hline Confidence Interval & 0.95 & 0.95 & 0.95 & 0.95 & 0.95 & 0.95 & 0.95 & 0.95 & 0.95 & 0.95 \\
\hline
\end{tabular}

$x i$-angular coefficient; $y i$-linear coefficient; $R^{2}$ —coefficient of determination; SE-Standard error; SQ-sum of squares; $n$-number of observations; DF-degrees of freedom; $\mathrm{t} \alpha / 2$-value of Student's t distribution. Different capital letters indicate significant differences by Fisher's (LSD) test $(p<0.05)$.

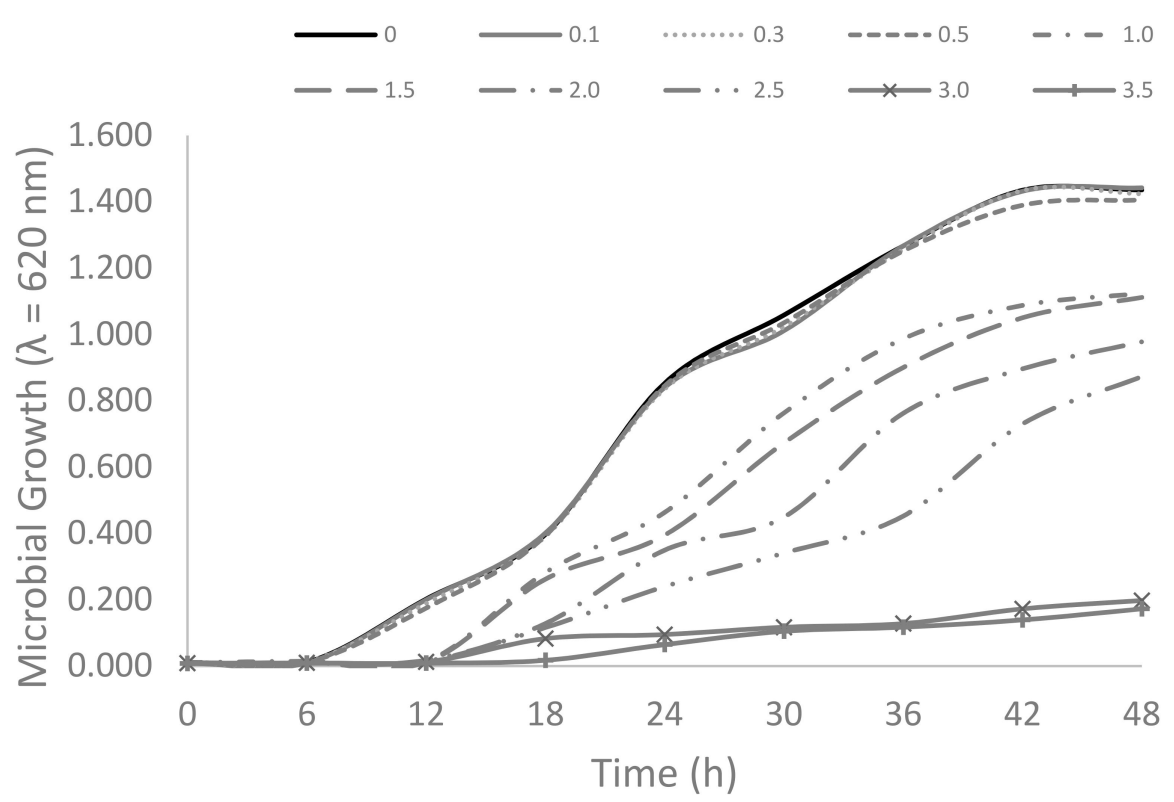

Figure 2. In vitro efficacy of PPCP against the growth of natural microbiota in vacuum-packaged cooked sausages. The inoculum was adjusted to ca. $5.5 \mathrm{log} \mathrm{cfu} / \mathrm{g}$ before testing, and the turbidity method was used to evaluate the efficacy.

Table 3 shows the physicochemical characterization, water activity measurements, and $\mathrm{pH}$ values of sausages.

PPCP and FCC 85 can reduce the growth of natural microbiota in vacuum-packaged cooked sausages and extend the shelf-life period. However, the strategy of addition must be carefully designed. The superficial treatments with $1.0 \%$ of PPCP and $2.0 \%$ of FCC 85 should be discouraged, since these treatments did not present effective results compared with blank and control. In the sausages' mass, the addition of 1.0\% PPCP was as effective as the addition of $2.0 \%$ of FCC 85 , indicating a potential natural alternative for product preservation (Table 4). 


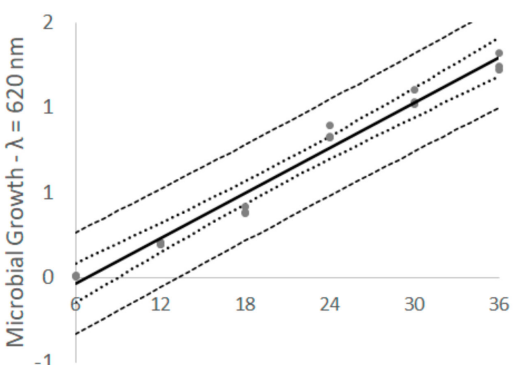

Time-hours

(a)

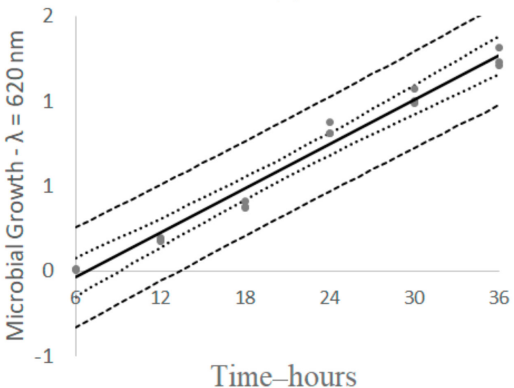

(c)

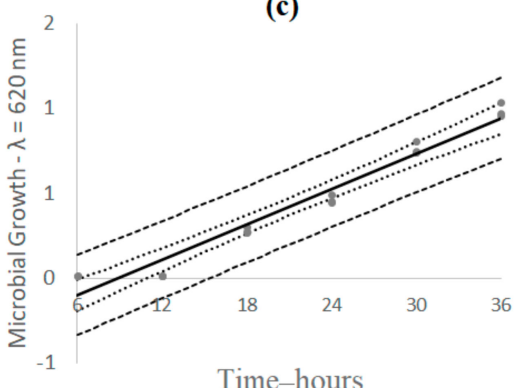

(e)

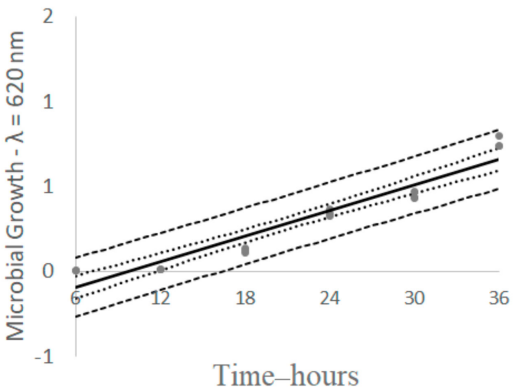

(g)

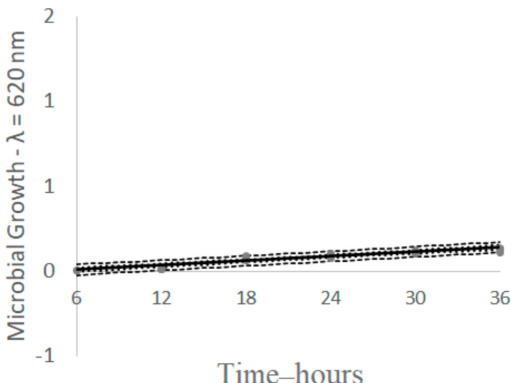

(i)

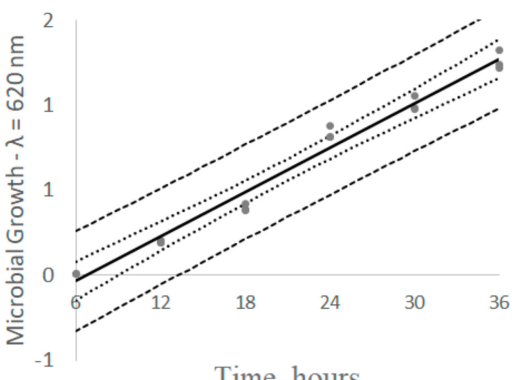

ime-hours

(b)

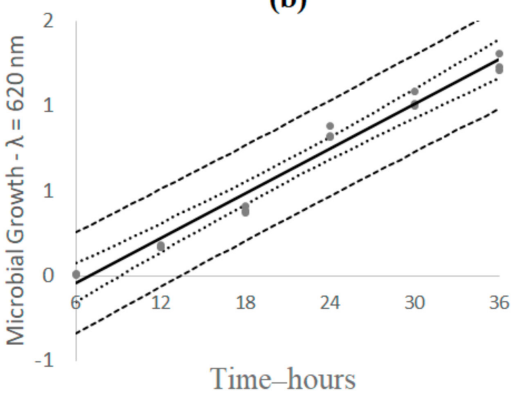

(d)

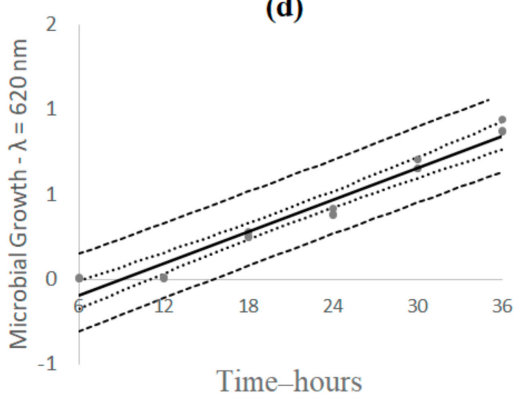

(f)

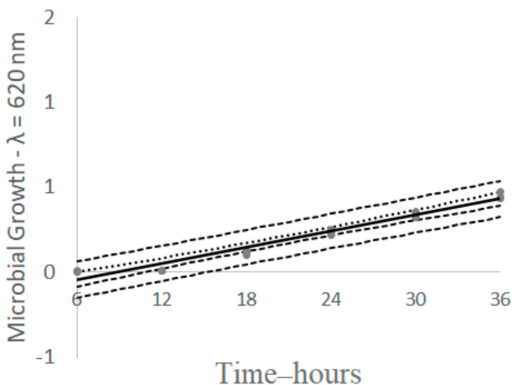

(h)

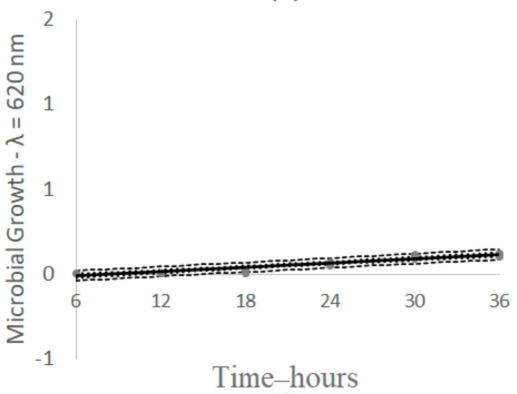

(j)

Figure 3. Linear regression (--), confidence interval for the mean (... .), and prediction interval for the sample (-) of the period with microbial growth (from 6 to $36 \mathrm{~h}$ of incubation at $36^{\circ} \mathrm{C}$ ) at different concentrations of potentially postbiotic-containing preservative (PPCP): (a) $0.0 \%$; (b) $0.1 \%$; (c) $0.3 \%$; (d) $0.5 \%$; (e) $1.0 \%$; (f) $1.5 \%$; (g) $2.0 \%$; (h) $2.5 \%$; (i) $3.0 \%$; (j) $3.5 \%$. 
Table 3. Physicochemical characterization of vacuum-packaged cooked sausages $(n=3)$.

\begin{tabular}{ccc}
\hline Parameter & \multicolumn{2}{c}{ Mean \pm Standard Error } \\
\hline Moisture (\%) & 56.663 & \pm 0.160 \\
Protein (\%) & 14.434 & \pm 0.288 \\
Fat (\%) & 23.550 & \pm 0.122 \\
Ash (\%) & 3.550 & \pm 0.387 \\
Carbohydrates 1 (\%) & 1.803 & \pm 0.627 \\
Total energy (kcal/100 g sample) & 281.749 & \pm 1.714 \\
Potential of hydrogen (pH) & 6.878 & \pm 0.004 \\
Water activity (Aw) & 0.964 & \pm 0.002 \\
\hline
\end{tabular}

${ }^{1}$ Calculated according to the Atwater specific factor system $(4.27 \mathrm{kcal} / \mathrm{g}$ for protein or carbohydrate and $9.02 \mathrm{kcal} / \mathrm{g}$ for fat).

Table 4. Durability study of vacuum-packaged cooked sausage samples.

\begin{tabular}{|c|c|c|c|c|c|c|c|c|c|c|c|c|c|}
\hline & & & & & \multicolumn{9}{|c|}{ Treatments } \\
\hline & \multicolumn{3}{|c|}{ Sample Incubation } & \multicolumn{5}{|c|}{ Sausage Surface } & \multicolumn{5}{|c|}{ Sausage Mass } \\
\hline & $\begin{array}{l}\text { Temperature } \\
\left({ }^{\circ} \mathrm{C}\right)\end{array}$ & $\begin{array}{l}\text { Time } \\
\text { (days) }\end{array}$ & Blank & $\begin{array}{c}\text { Control } \\
\text { (water) } \\
2.0 \%\end{array}$ & $\begin{array}{l}\text { Sodium } \\
\text { lactate } \\
2.0 \%\end{array}$ & $\begin{array}{c}\mathrm{PPCP}^{4} \\
1.0 \%\end{array}$ & $\begin{array}{l}\text { PPCP } \\
2.0 \%\end{array}$ & $\begin{array}{l}\text { PPCP } \\
3.0 \%\end{array}$ & $\begin{array}{c}\text { Control } \\
\text { (water) } \\
2.0 \%\end{array}$ & $\begin{array}{l}\text { Sodium } \\
\text { lactate } \\
2.0 \%\end{array}$ & $\begin{array}{l}\text { PPCP } \\
1.0 \%\end{array}$ & $\begin{array}{l}\text { PPCP } \\
2.0 \%\end{array}$ & $\begin{array}{l}\text { PPCP } \\
3.0 \%\end{array}$ \\
\hline \multirow{5}{*}{$\begin{array}{l}\text { Laboratorial data } \\
\qquad(\log \mathrm{cfu} / \mathrm{g})\end{array}$} & & 0 & 5.77 & 5.80 & 5.71 & 5.88 & 5.79 & 5.80 & 5.66 & 5.76 & 5.81 & 5.83 & 5.87 \\
\hline & \multirow{2}{*}{7} & 3 & 6.01 & 5.99 & 5.89 & 5.99 & 5.90 & 5.81 & 5.95 & 6.01 & 6.02 & 5.92 & 6.01 \\
\hline & & 6 & 6.49 & 6.48 & 6.37 & 6.45 & 6.23 & 5.98 & 6.42 & 6.14 & 6.09 & 6.00 & 6.32 \\
\hline & \multirow[b]{2}{*}{36} & 2 & 6.69 & 6.72 & 6.70 & 6.80 & 6.64 & 6.14 & 6.59 & 6.66 & 6.61 & 6.33 & 6.26 \\
\hline & & 4 & 8.50 & 8.48 & 8.49 & 8.61 & 8.45 & 6.87 & 8.42 & 7.12 & 7.10 & 6.97 & 6.94 \\
\hline \multirow{4}{*}{$\begin{array}{c}\text { Specific } \\
\text { maximum } \\
\text { growth rate } \\
(\log \mathrm{cfu} / \mathrm{g} / \text { day })\end{array}$} & \multirow{2}{*}{7} & L phase & 0.1000 & 0.0883 & 0.0850 & 0.0658 & 0.0550 & 0.0167 & 0.1117 & 0.0733 & 0.0583 & 0.0292 & 0.0608 \\
\hline & & D phase & 0.0287 & 0.0253 & 0.0244 & 0.0189 & 0.0158 & 0.0048 & 0.0320 & 0.0210 & 0.0167 & 0.0084 & 0.0174 \\
\hline & \multirow[b]{2}{*}{36} & L phase & 0.5713 & 0.5650 & 0.5950 & 0.5713 & 0.5450 & 0.2188 & 0.5775 & 0.3950 & 0.3613 & 0.2675 & 0.2313 \\
\hline & & D phase & 0.1637 & 0.1619 & 0.1705 & 0.1637 & 0.1562 & 0.0627 & 0.1655 & 0.1132 & 0.1035 & 0.0767 & 0.0663 \\
\hline & & Season & & & & & & & & & & & \\
\hline \multirow{4}{*}{$\begin{array}{c}\text { Ngrowth } \\
(\log \text { cfu/g/day })^{1}\end{array}$} & & Summer & 0.4649 & 0.4575 & 0.4800 & 0.4572 & 0.4345 & 0.1732 & 0.4724 & 0.3224 & 0.2929 & 0.2137 & 0.1928 \\
\hline & & Autumn & 0.2970 & 0.2876 & 0.2982 & 0.2771 & 0.2599 & 0.1012 & 0.3064 & 0.2078 & 0.1850 & 0.1288 & 0.1321 \\
\hline & & Winter & 0.2158 & 0.2054 & 0.2103 & 0.1900 & 0.1754 & 0.0663 & 0.2261 & 0.1524 & 0.1328 & 0.0877 & 0.0608 \\
\hline & & Spring & 0.3383 & 0.3294 & 0.3429 & 0.3214 & 0.3028 & 0.1189 & 0.3473 & 0.2360 & 0.2115 & 0.1497 & 0.1470 \\
\hline \multirow{4}{*}{$\begin{array}{c}\text { Ndeceleration } \\
(\log \mathrm{cfu} / \mathrm{g} / \text { day })^{2}\end{array}$} & & Summer & 0.1332 & 0.1311 & 0.1375 & 0.1310 & 0.1245 & 0.0496 & 0.1354 & 0.0924 & 0.0839 & 0.0613 & 0.0553 \\
\hline & & Autumn & 0.1151 & 0.1115 & 0.1156 & 0.1074 & 0.1007 & 0.0392 & 0.1188 & 0.0805 & 0.0717 & 0.0499 & 0.0512 \\
\hline & & Winter & 0.1008 & 0.0960 & 0.0983 & 0.0888 & 0.0820 & 0.0310 & 0.1057 & 0.0712 & 0.0620 & 0.0410 & 0.0284 \\
\hline & & Spring & 0.1207 & 0.1175 & 0.1223 & 0.1146 & 0.1080 & 0.0424 & 0.1239 & 0.0842 & 0.0754 & 0.0534 & 0.0524 \\
\hline \multirow{4}{*}{$\begin{array}{l}\text { Use-by date } \\
\text { (days) }^{3}\end{array}$} & & Summer & 12 & 12 & 12 & 12 & 14 & 34 & 12 & 19 & 20 & 27 & 30 \\
\hline & & Autumn & 17 & 18 & 17 & 18 & 20 & 50 & 17 & 24 & 27 & 38 & 37 \\
\hline & & Winter & 22 & 22 & 22 & 24 & 26 & 70 & 21 & 31 & 35 & 52 & 45 \\
\hline & & Spring & 15 & 16 & 15 & 16 & 17 & 43 & 15 & 23 & 25 & 35 & 35 \\
\hline
\end{tabular}

${ }^{1}$ Ngrowth - daily microbial population growth $(\log \mathrm{cfu} / \mathrm{g})$ in the microbial growth $(\log )$ phase ${ }^{2}$ Ndecelerationdaily microbial population growth $(\log \mathrm{cfu} / \mathrm{g})$ in the microbial deceleration phase; ${ }^{3}$ the use-by dates for vacuumpackaged cooked sausages were established when spoilage microbial load achieved the maximum limit of ca. $9.3 \log \mathrm{cfu} / \mathrm{g} .{ }^{4} \mathrm{PPCP}-$ potentially postbiotic-containing preservative.

The temperature profile entered in the predictive model influenced the growth of the natural microbiota in vacuum-packaged cooked sausages. In summer, the values of the Ngrowth and Ndeceleration parameters of the predictive model, which represent the kinetics of the microbial growth in the growth (log) and deceleration phases, respectively, were higher than the values obtained during the other seasons. Thus, a shorter shelf life was observed during summer, with an early achievement of the predictive borderline limit, which can result in changes in sensory attributes related to sausages' appearance. As expected, microbial growth was reduced in winter. The correlation variable factor $F T(n)$, which describes specific growth rates between log and deceleration phases, can also be used to indicate the impact of the temperature profile on microbial growth, highlighting that the critical period for sausage preservation was summer $(F T(n)=3.4894)$, followed by autumn $(F T(n)=2.8038)$, spring $(F T(n)=2.5801)$, and winter $(F T(n)=2.1401)$ 


\section{Discussion}

Over the past decade, novel terms have been used to represent the beneficial effects of microorganisms. Postbiotics, or paraprobiotics or metabiotics, represent structural components of probiotic microorganisms and/or formulation of signaling molecules with a known chemical structure that can optimize host-specific physiological functions and regulate metabolic and/or behavior reactions related to the activity of host natural microbiota [28-30].

Hill et al. (2014) proposed that a more grammatically correct definition of probiotics would be 'live microorganisms that, when administered in adequate amounts, confer a health benefit on the host'. Thus, FAO and WHO definition of probiotics was reinforced as relevant and adaptable for current and further applications [31,32]. The development of metabolic by-products, dead microorganisms, or other microbial-based, nonviable products has potential; however, these do not fall under the probiotic construct'.

Once the viability of Lacticaseibacillus is reduced by cooking, postbiotic compounds can be a suitable alternative for the development of functional cooked foods. Moreover, precultured medium by LAB has been reported in the literature as a promising natural technology for food preservation [33].

Poor-quality raw material and inadequate handling can anticipate sausage spoilage. In vacuum-packaged cooked sausages, changes in the sensory attributes related to the sausages' appearance, which can be a decisive factor for consumer appraisal, occur when the microbial population achieves the stationary phase in the microbial growth curve (ca. $9.3 \mathrm{log}$ cfu/g) (Figures S2 and S3, Table S1). The use of preservatives may reduce the activity of the natural microbiota, impacting the cell viability.

None of the treatments maintained the microbial load below the predicted model's borderline during the 90 days of shelf life indicated by the meat industry. Therefore, additional hurdles, such as cold storage, should be used combined with preservatives. When the cold storage temperature profile $\left(7^{\circ} \mathrm{C}\right)$ was entered in the predictive model to estimate the use-by date of the sausages, adding $3.0 \%$ of PPCP on the surface or adding $2.0 \%$ or more to the mass extended the use-by date by more than 90 days (Table 5).

Table 5. Durability study of vacuum-packaged cooked sausages stored at $7{ }^{\circ} \mathrm{C}$.

\begin{tabular}{|c|c|c|c|c|c|c|c|c|c|c|c|c|c|}
\hline & \multicolumn{3}{|c|}{ Sample Incubation } & \multicolumn{5}{|c|}{ Sausage Surface } & \multicolumn{5}{|c|}{ Sausage Mass } \\
\hline & $\begin{array}{l}\text { Temperature } \\
\left({ }^{\circ} \mathrm{C}\right)\end{array}$ & $\begin{array}{l}\text { Time } \\
\text { (days) }\end{array}$ & Blank & $\begin{array}{c}\text { Control } \\
\text { (water) } \\
2.0 \%\end{array}$ & $\begin{array}{l}\text { Sodium } \\
\text { lactate } \\
2.0 \%\end{array}$ & $\begin{array}{c}\mathrm{PPCP}^{4} \\
1.0 \%\end{array}$ & $\begin{array}{l}\mathrm{PPCP} \\
2.0 \%\end{array}$ & $\begin{array}{l}\mathrm{PPCP} \\
3.0 \%\end{array}$ & $\begin{array}{c}\text { Control } \\
\text { (water) } \\
2.0 \%\end{array}$ & $\begin{array}{l}\text { Sodium } \\
\text { lactate } \\
2.0 \%\end{array}$ & $\begin{array}{l}\text { PPCP } \\
1.0 \%\end{array}$ & $\begin{array}{l}\mathrm{PPCP} \\
2.0 \%\end{array}$ & $\begin{array}{c}\text { PPCP } \\
3.0 \%\end{array}$ \\
\hline \multirow{3}{*}{$\begin{array}{l}\text { Laboratorial data } \\
\quad(\log \mathrm{cfu} / \mathrm{g})\end{array}$} & & 0 & 5.77 & 5.80 & 5.71 & 5.88 & 5.79 & 5.80 & 5.66 & 5.76 & 5.81 & 5.83 & 5.87 \\
\hline & 7 & $\begin{array}{l}3 \\
6\end{array}$ & $\begin{array}{l}6.01 \\
6.49\end{array}$ & $\begin{array}{l}5.99 \\
6.48\end{array}$ & $\begin{array}{l}5.89 \\
6.37\end{array}$ & $\begin{array}{l}5.99 \\
6.45\end{array}$ & $\begin{array}{l}5.90 \\
6.23\end{array}$ & $\begin{array}{l}5.81 \\
5.98\end{array}$ & $\begin{array}{l}5.95 \\
6.42\end{array}$ & $\begin{array}{l}6.01 \\
6.14\end{array}$ & $\begin{array}{l}6.02 \\
6.09\end{array}$ & $\begin{array}{c}5.92 \\
6\end{array}$ & $\begin{array}{l}6.01 \\
6.32\end{array}$ \\
\hline & 36 & $\begin{array}{l}2 \\
4\end{array}$ & $\begin{array}{l}6.69 \\
8.50\end{array}$ & $\begin{array}{l}6.72 \\
8.48\end{array}$ & $\begin{array}{l}6.70 \\
8.49\end{array}$ & $\begin{array}{l}6.80 \\
8.61\end{array}$ & $\begin{array}{l}6.64 \\
8.45\end{array}$ & $\begin{array}{l}6.14 \\
6.87\end{array}$ & $\begin{array}{l}6.59 \\
8.42\end{array}$ & $\begin{array}{l}6.66 \\
7.12\end{array}$ & $\begin{array}{l}6.61 \\
7.10\end{array}$ & $\begin{array}{l}6.33 \\
6.97\end{array}$ & $\begin{array}{l}6.26 \\
6.94\end{array}$ \\
\hline \multirow{2}{*}{$\begin{array}{l}\text { Specific maximum } \\
\text { growth rate } \\
(\log \mathrm{cfu} / \mathrm{g} / \text { day })\end{array}$} & 7 & $\begin{array}{l}\text { L phase } \\
\text { D phase }\end{array}$ & $\begin{array}{l}0.1000 \\
0.0287\end{array}$ & $\begin{array}{l}0.0883 \\
0.0253\end{array}$ & $\begin{array}{l}0.0850 \\
0.0244\end{array}$ & $\begin{array}{l}0.0658 \\
0.0189\end{array}$ & $\begin{array}{l}0.0550 \\
0.0158\end{array}$ & $\begin{array}{l}0.0167 \\
0.0048\end{array}$ & $\begin{array}{l}0.1117 \\
0.0320\end{array}$ & $\begin{array}{l}0.0733 \\
0.0210\end{array}$ & $\begin{array}{l}0.0583 \\
0.0167\end{array}$ & $\begin{array}{l}0.0292 \\
0.0084\end{array}$ & $\begin{array}{l}0.0608 \\
0.0174\end{array}$ \\
\hline & 36 & $\begin{array}{l}\text { L phase } \\
\text { D phase }\end{array}$ & $\begin{array}{l}0.5713 \\
0.1637\end{array}$ & $\begin{array}{l}0.5650 \\
0.1619\end{array}$ & $\begin{array}{l}0.5950 \\
0.1705\end{array}$ & $\begin{array}{l}0.5713 \\
0.1637\end{array}$ & $\begin{array}{l}0.5450 \\
0.1562\end{array}$ & $\begin{array}{l}0.2188 \\
0.0627\end{array}$ & $\begin{array}{l}0.5775 \\
0.1655\end{array}$ & $\begin{array}{l}0.3950 \\
0.1132\end{array}$ & $\begin{array}{l}0.3613 \\
0.1035\end{array}$ & $\begin{array}{l}0.2675 \\
0.0767\end{array}$ & $\begin{array}{l}0.2313 \\
0.0663\end{array}$ \\
\hline $\begin{array}{c}\text { Ngrowth } \\
(\log \mathrm{cfu} / \mathrm{g} / \text { day })^{1}\end{array}$ & & & 0.1000 & 0.0883 & 0.0850 & 0.0658 & 0.0550 & 0.0167 & 0.1117 & 0.0733 & 0.0583 & 0.0292 & 0.0250 \\
\hline $\begin{array}{c}\text { Ndeceleration } \\
(\log \mathrm{cfu} / \mathrm{g} / \text { day })^{2}\end{array}$ & & & 0.0661 & 0.0584 & 0.0562 & 0.0435 & 0.0363 & 0.0110 & 0.0738 & 0.0485 & 0.0386 & 0.0193 & 0.0165 \\
\hline Use-by date (days) ${ }^{3}$ & & & 41 & 46 & 49 & 60 & 73 & 240 & 38 & 56 & 68 & 136 & 158 \\
\hline
\end{tabular}

The addition of $2.0 \%$ of FCC 85 on the surface or to the mass of the sausages little increased the use-by date. However, this is close to the maximum concentration permitted by the regulatory agency for the use of sodium lactate in heat-treated meat products [34]. This fact casts doubt on the efficacy of sodium lactate in increasing the use-by date of 
vacuum-packaged cooked sausages. Although PPCP showed advantages compared with FCC85 regarding the extension of the use-by date of the sausages, it did not maintain the microbial load below the predictive model's borderline over 90 days either. However, there is no prescribed limit on the use of natural substances in sausages. Moreover, co-use of preservatives and proper management of the cold chain are suitable strategies to achieve a use-by date higher than 90 days.

Cold chain management of meat products, including raw material supply, processing, distribution, and retail, is a crucial factor to prevent spoilage [12]. The specific maximum growth rate obtained at $36{ }^{\circ} \mathrm{C}$ was expressively higher than the value determined at $7{ }^{\circ} \mathrm{C}$ (Table 2), showing the influence of the temperature on sausage spoilage. Indeed, the temperature profile during distribution, storage, and disposal in the market plays a role in the durability of meat products.

The addition of $3.0 \%$ of PPCP on the surface or $2.0 \%$ or more of PPCP to the mass, combined with management of the cold chain, resulted in a use-by date higher than 90 days (Table 5).

These results highlighted the potential use of PPCP on the surface of sausages. However, the concentration to achieve total inhibition of the microbiota, determined in vitro, should be respected. Thus, regarding the addition of PPCP to the mass of the sausages, the concentrations used to achieve partial inhibition of the microbiota can be used.

After packaging, syneresis may be induced during the storage and distribution of sausages, resulting in the accumulation of water, nutrients, and microorganisms inside the package. Preservatives are usually added to the mass with other ingredients during meat products preparation. However, there are no barriers to prevent microbial growth in the liquid accumulated inside the package after syneresis. Even when effective preservatives are added to the mass, this strategy may fail after syneresis because of the partial migration of these additives to the liquid phase. It can be of great concern if the storage temperature allows microbial activity.

The initial microbial load of the sausages may contribute to shortening the use-by date. By fixing the values of predictive model's parameters (Ngrowth, Ndeceleration, and Ft $(n)$ ) for each treatment, a use-by date of 90 days was achieved with the predicted initial microbial loads presented in Table 6.

Table 6. Estimated initial microbial load of vacuum-packaged cooked sausages to achieve the predictive model's borderline of 90 days.

\begin{tabular}{|c|c|c|c|c|c|c|}
\hline & \multirow[b]{2}{*}{ Treatments } & \multicolumn{5}{|c|}{ Presumed Initial Microbial Load (log cfu/g) } \\
\hline & & Summer & Autumn & Winter & Spring & Cold Storage \\
\hline & Blank & -20.00 & -13.05 & -9.03 & -14.90 & 0.87 \\
\hline \multirow{5}{*}{ Sausage surface } & $2.0 \%$ of water (control) & -19.17 & -12.22 & -8.20 & -14.07 & 1.90 \\
\hline & $2.0 \%$ of sodium lactate & -19.46 & -12.51 & -8.49 & -14.36 & 2.21 \\
\hline & $1.0 \%$ of $\mathrm{PPCP}^{1}$ & -17.59 & -10.64 & -6.62 & -12.49 & 3.88 \\
\hline & $2.0 \%$ of $\mathrm{PPCP}$ & -16.38 & -9.43 & -5.41 & -11.28 & 4.84 \\
\hline & $3.0 \%$ of $\mathrm{PPCP}$ & -6.57 & 0.38 & 4.40 & -1.47 & 8.30 \\
\hline \multirow{5}{*}{ Sausage mass } & $2.0 \%$ of water (control) & -20.91 & -13.96 & -9.94 & -15.81 & -0.24 \\
\hline & $2.0 \%$ of sodium lactate & -14.21 & -7.26 & -3.24 & -9.11 & 3.26 \\
\hline & $1.0 \%$ of PРCP & -12.46 & -5.51 & -1.49 & -7.36 & 4.56 \\
\hline & $2.0 \%$ of PPCP & -7.62 & -0.67 & 3.35 & -2.52 & 7.18 \\
\hline & $3.0 \%$ of $\mathrm{PPCP}$ & -6.27 & 0.68 & 4.70 & -1.17 & 7.57 \\
\hline
\end{tabular}

${ }^{1} \mathrm{PPCP}$ - potentially postbiotic-containing preservative.

Only the treatments with $3.0 \%$ of PPCP on the surface or $2.0 \%$ or more of PPCP in the mass of the sausages during the winter achieved the proposed use-by date. This result highlights the importance of considering additional factors to hurdle microbial growth in the sausages. During summer and spring, sausage preservation during the proposed use-by date was elusive for any treatment. With the co-use of preservatives and the management 
of cold chain, the meat industry may reduce the initial microbial load to the levels presented in Table 6.

Satisfactory results regarding the extension of the shelf life of meat products can be achieved by reducing the initial microbial load, as well as by improving the product formulation to prevent syneresis [35]. Indeed, the microbial growth and durability of sausages are greatly influenced by the initial microbial load and the use of effective hurdles [36]. However, sporulated bacteria groups cannot be eliminated by cooking processes and hurdlers. This fact highlights the importance of avoiding the presence of these microorganisms in products by applying microbiological quality control in the meat supply chain [37].

Handlers, utensils, equipment, and microbial load of the raw material are the main microbial vehicles during production [38-40]. The environment is also a factor in meat spoilage [41], and it depends on the region; climate; microclimate, season; and anomalous environmental events such as forest fires, deforestation, rainwater excess, etc. [42].

\section{Conclusions}

PPCP produced by an axenic fermentation system with L. paracasei DTA 83 was as effective as the reference widespread commercial preservative FCC85 in preserving vacuum-packaged cooked sausages. Thus, it can be highlighted as a promising alternative concerning the use of natural technologies to preserve and produce functional cooked sausages. These results also revealed a logical relation regarding in vitro and in situ tests to evaluate sausage preservation. The concentration needed to achieve total inhibition of the microbiota, determined by an in vitro trial, should be respected when adding PPCP on sausages' surface. When adding PPCP to the mass of the sausages, the concentration that showed a partial inhibition in vitro could also be applied in situ. However, proper chain management during distribution and disposal of products in the market are pivotal to achieve the desired use-by date. Although this study presented a potential postbiotic alternative by adding PPCP to sausages, a robust in vivo trial must be further designed to evaluate effects in the host.

Supplementary Materials: The following supporting information can be downloaded at: https: / / www.mdpi.com/article/10.3390/fermentation8030106/s1, Figure S1: (a) Cluster analysis of RADPPCR profiles obtained of 35 Lacticaseibacillus isolates from stool samples of infants aged between 7 to 21 days. The amplification patterns were analyzed using the software Gel Compar 4.1 (Applied Maths) [1], and (b) potential of Lacticaseibacillus to acidify the pasteurized deMan, Rogosa and Sharp broth medium.; Figure S2: The relative abundance (a and b), Krona plot (c), and dendrogram of similarities and discrepancies of high-throughput sequencing of bacterial phyla of vacuum-packaged cooked sausages; Figure S3: Microbial growth curves at $4{ }^{\circ} \mathrm{C}(\mathrm{a}), 12{ }^{\circ} \mathrm{C}(\mathrm{b}), 24{ }^{\circ} \mathrm{C}$ (c), and $36{ }^{\circ} \mathrm{C}$ (d). They were plotted regarding the natural microbiota of vacuum-packaged cooked sausages ( $\bullet$ sample \#1 $\backslash ;-$ sample \#2 $\backslash ;--^{-}$sample \#3). Drop-plate technique was used to count total bacteria. Baranyi's mathematical model was applied to model the microbial growth at each temperature. The initial population was ca. $2.8 \log \mathrm{cfu} / \mathrm{g}$. The growth $(\mathrm{log})$ phase started suddenly after incubation at 24 and $36{ }^{\circ} \mathrm{C}$, and extended up to $8.2 \mathrm{log} \mathrm{cfu} / \mathrm{g}$. Stationary phase started after the population had reached ca. $9.3 \log \mathrm{cfu} / \mathrm{g}$. The period between the log and the stationary phases was considered the deceleration phase; Figure S4. Sample incubation design. Microbial count at time zero must be below $8.2 \mathrm{log} \mathrm{cfu} / \mathrm{g}$ to validate the test. Besides the time zero, there is no predefined time for microbial counting once the computational predictive modeling can process any time; however, microbial growth (log) phase must be included at least in one of the counts. Laboratories can determine the incubation temperatures; however, lower and higher temperatures between 4 and $20{ }^{\circ} \mathrm{C}, 25$ and $36^{\circ} \mathrm{C}$, respectively, must be used; Figure S5. Illustration of the biological growth curve by predictive modeling. A-adaptation and acceleration growth phase; L-microbial growth (log) phase; D-deceleration phase; S-stationary phase. Correlations between specific growth rate in L and D phases were performed based on the correlation factor FT(n) value, according to the chosen temperature profile of the test; Table S1. Instrumental color measurement (on the unopened packaged sausages and after withdrawing the sausages from the packages and cleaning up their surfaces) and slime formation detection $[43,44]$. 


\begin{abstract}
Author Contributions: Conceptualization, A.L.d.L., C.A.G., L.M.C. and A.F.G.; validation, W.J.F.L.J.; writing - original draft preparation, A.F.G.; writing-review and editing, V.S.d.O.; supervision, R.H.L. and A.F.G. All authors have read and agreed to the published version of the manuscript.
\end{abstract}

Funding: This research received no external funding.

Institutional Review Board Statement: Not applicable.

Informed Consent Statement: Not applicable.

Data Availability Statement: Not applicable.

Acknowledgments: The authors are grateful to BRC Ingredients (Rio Claro, São Paulo) for its sponsorship.

Conflicts of Interest: The authors declare no conflict of interest.

\title{
References
}

1. Mozzi, F. Lactic Acid Bacteria. In Encyclopedia of Food and Health; Caballero, B., Finglas, P.M., Toldrá, F.B.T.-E., Eds.; Academic Press: Oxford, UK, 2016; pp. 501-508. ISBN 978-0-12-384953-3.

2. Ruiz Rodríguez, L.G.; Mohamed, F.; Bleckwedel, J.; Medina, R.; De Vuyst, L.; Hebert, E.M.; Mozzi, F. Diversity and functional properties of lactic acid bacteria isolated from wild fruits and flowers present in northern Argentina. Front. Microbiol. 2019, 10, 1091. [CrossRef] [PubMed]

3. Tarrah, A.; da Silva Duarte, V.; de Castilhos, J.; Pakroo, S.; Lemos Junior, W.J.F.; Luchese, R.H.; Fioravante Guerra, A.; Rossi, R.C.; Righetto Ziegler, D.; Corich, V.; et al. Probiotic potential and biofilm inhibitory activity of Lactobacillus casei group strains isolated from infant feces. J. Funct. Foods 2019, 54, 489-497. [CrossRef]

4. $\quad$ Laureano-Melo, R.; Caldeira, R.F.; Guerra, A.F.; Conceição, R.R.D.; Souza, J.S.D.; Giannocco, G.; Marinho, B.G.; Luchese, R.H.; Côrtes, W.S. Maternal supplementation with Lactobacillus paracasei DTA 83 alters emotional behavior in Swiss mice offspring. PharmaNutrition 2019, 8, 100148. [CrossRef]

5. $\quad$ Silva, L.C.; Lago, H.S.; Rocha, M.O.T.; Oliveira, V.S.; Laureano-Melo, R.; Stutz, E.T.G.; Paula, B.P.; Martins, J.F.P.; Luchese, R.H.; Guerra, A.F.; et al. Craft beers fermented by potential probiotic yeast or lacticaseibacilli strains promote antidepressant-like behavior in Swiss Webster mice. Probiotics Antimicrob. Proteins 2021, 13, 698-708. [CrossRef]

6. Food Safety Authority of Ireland. Guidance Note, No. 18 Validation of Products Shelf-Life, 4th ed.; Food Safety Authority of Ireland: Dublin, Ireland, 2019; ISBN 904465-33.

7. Smet, C.; Baka, M.; Steen, L.; Fraeye, I.; Walsh, J.L.; Valdramidis, V.P.; Van Impe, J.F. Combined effect of cold atmospheric plasma, intrinsic and extrinsic factors on the microbial behavior in/on (food) model systems during storage. Innov. Food Sci. Emerg. Technol. 2019, 53, 3-17. [CrossRef]

8. Horita, C.N.; Baptista, R.C.; Caturla, M.Y.R.; Lorenzo, J.M.; Barba, F.J.; Sant'Ana, A.S. Combining reformulation, active packaging and non-thermal post-packaging decontamination technologies to increase the microbiological quality and safety of cooked ready-to-eat meat products. Trends Food Sci. Technol. 2018, 72, 45-61. [CrossRef]

9. Jaramillo, L.; Santos, D.; Borges, E.; Dias, D.; Pereira, N. Low-cost effective culture medium optimization for d-lactic acid production by Lactobacillus coryniformis subsp. torquens under oxygen-deprived condition. Ann. Microbiol. 2018, 68, 547-555. [CrossRef]

10. Göransson, M.; Nilsson, F.; Jevinger, Å. Temperature performance and food shelf-life accuracy in cold food supply chains-Insights from multiple field studies. Food Control 2018, 86, 332-341. [CrossRef]

11. Opara, U.L.; Caleb, O.J.; Belay, Z.A. 7-Modified atmosphere packaging for food preservation. In Food Quality and Shelf Life; Galanakis, C.M., Ed.; Academic Press: Oxford, UK, 2019; pp. 235-259, ISBN 978-0-12-817190-5.

12. Kolbeck, S.; Ludwig, C.; Meng, C.; Hilgarth, M.; Vogel, R.F. Comparative Proteomics of Meat Spoilage Bacteria Predicts Drivers for Their Coexistence on Modified Atmosphere Packaged Meat. Front. Microbiol. 2020, 11, 209. [CrossRef]

13. Brewer, M.S.; Mckeith, F.; Martin, S.E.; Dallmier, A.W.; Meyer, J. Sodium lactate effects on shelf-life, sensory, and physical characteristics of fresh pork sausage. J. Food Sci. 1991, 56, 1176-1178. [CrossRef]

14. Feng, Q.; Yang, Z.; May, M.; Tsoi, K.K.; Ingle, S.; Lee, E.K.; Wong, S.Y.; Kim, J.H. The role of body mass index in the association between dietary sodium intake and blood pressure: A mediation analysis with Nhanes. Nutr. Metab. Cardiovasc. Dis. 2021, 31, 3335-3344. [CrossRef] [PubMed]

15. Castellano, P.; Pérez Ibarreche, M.; Blanco Massani, M.; Fontana, C.; Vignolo, G.M. Strategies for pathogen biocontrol using lactic acid bacteria and their metabolites: A focus on meat ecosystems and industrial environments. Microorganisms 2017, 5, 38. [CrossRef] [PubMed]

16. Martín, I.; Rodríguez, A.; Delgado, J.; Córdoba, J.J. Strategies for biocontrol of Listeria monocytogenes using lactic acid bacteria and their metabolites in ready-to-eat meat- and dairy-ripened products. Foods 2022, 11, 542. [CrossRef] [PubMed]

17. Hernández-Aquino, S.; Miranda-Romero, L.A.; Fujikawa, H.; Maldonado-Simán, E.M.A.D.E.J.; Alarcón-Zuñiga, B. Antibacterial activity of lactic acid bacteria to improve shelf life of raw meat. Biocontrol Sci. 2019, 24, 185-192. [CrossRef] 
18. Oliveira, W.A.; Rodrigues, A.R.P.; Oliveira, F.A.; Oliveira, V.S.; Laureano-Melo, R.; Stutz, E.T.G.; Lemos Junior, W.J.F.; Paula, B.P.; Esmerino, E.A.; Corich, V.; et al. Potentially probiotic or postbiotic pre-converted nitrite from celery produced by an axenic culture system with probiotic lacticaseibacilli strain. Meat Sci. 2021, 174, 108408. [CrossRef]

19. Silva, L.C.; Schmidt, G.B.; Alves, L.G.O.; Oliveira, V.S.; Laureano-Melo, R.; Stutz, E.; Martins, J.F.P.; Paula, B.P.; Luchese, R.H.; Guerra, A.F.; et al. Use of probiotic strains to produce beers by axenic or semi-separated co-culture system. Food Bioprod. Process. 2020, 124, 408-418. [CrossRef]

20. Lemos Junior, W.J.F.; Guerra, A.F.; Tarrah, A.; Duarte, V.S.; Giacomini, A.; Luchese, R.H.; Corich, V. Safety and stability of two potentially probiotic Lactobacillus strains after in vitro gastrointestinal transit. Probiotics Antimicrob. Proteins 2019, 12, 657-666. [CrossRef]

21. Guerra, A.F.; Lemos Junior, W.J.F.; Santos, G.O.; Andrighetto, C.; Giacomini, A.; Corich, V.; Luchese, R.H. Lactobacillus paracasei probiotic properties and survivability under stress-induced by processing and storage of ice cream bar or ice-lolly. Ciência Rural 2018, 48, 9. [CrossRef]

22. Lemos Junior, W.J.F.; Guerra, A.F.; Duarte, V.S.; Treu, L.; Tarrah, A.; Campanaro, S.; Luchese, R.H.; Giacomini, A.; Corich, V. Draft genome sequence data of Lactobacillus paracasei strain DTA83 isolated from infant stools. Data Br. 2019, 22, 1064-1067. [CrossRef]

23. Horwitz, W.; Latimer, G.W. Official Methods of Analysis of AOAC International; AOAC International: Gaithersburg, MD, USA, 2005.

24. ISO 18787:2017; Foodstuffs_Determination of Water Activity. ISO: Geneva, Switzerland, 2017.

25. ISO 2917:1999(E); Meat and Meat Products-Measurement of pH—Reference Method. ISO: Geneva, Switzerland, 1999.

26. ISO 4833-1:2013; Microbiology of the Food Chain-Horizontal Method for the Enumeration of Microorganisms-Part 1: Colony Count at 30 Degrees $C$ by the Pour Plate Technique-Reference Method. ISO: Geneva, Switzerland, 2013.

27. Peel, M.C.; Finlayson, B.L.; McMahon, T.A. Updated world map of the Köppen-Geiger climate classification. Hydrol. Earth Syst. Sci. 2007, 11, 1633-1644. [CrossRef]

28. Tsilingiri, K.; Barbosa, T.; Penna, G.; Caprioli, F.; Sonzogni, A.; Viale, G.; Rescigno, M. Probiotic and postbiotic activity in health and disease: Comparison on a novel polarised ex-vivo organ culture model. Gut 2012, 61, 1007-1015. [CrossRef] [PubMed]

29. Taverniti, V.; Guglielmetti, S. The immunomodulatory properties of probiotic microorganisms beyond their viability (ghost probiotics: Proposal of paraprobiotic concept). Genes Nutr. 2011, 6, 261-274. [CrossRef] [PubMed]

30. Shenderov, B.A. Metabiotics: Novel idea or natural development of probiotic conception. Microb. Ecol. Heal. Dis. 2013, 24, 20399. [CrossRef] [PubMed]

31. Food and Agriculture Organization. FAO/WHO Guidelines for the Evaluation of Probiotics in Food; FAO: Rome, Italy, $2002 ;$ p. 11.

32. Hill, C.; Guarner, F.; Reid, G.; Gibson, G.R.; Merenstein, D.J.; Pot, B.; Morelli, L.; Canani, R.B.; Flint, H.J.; Salminen, S.; et al. Expert consensus document: The international scientific association for probiotics and prebiotics consensus statement on the scope and appropriate use of the term probiotic. Nat. Rev. Gastroenterol. Hepatol. 2014, 11, 506-514. [CrossRef] [PubMed]

33. Cebrián, G.; Condón, S.; Mañas, P. Physiology of the inactivation of vegetative bacteria by thermal treatments: Mode of action, influence of environmental factors and inactivation kinetics. Foods 2017, 6, 107. [CrossRef] [PubMed]

34. EFSA Regulation (EC) No 1333/2008 of the European Parliament and of the Council of 16 December 2008 on food additives. Off. J. Eur. Union 2008, 336, 16-33.

35. Bouju-Albert, A.; Pilet, M.-F.; Guillou, S. Influence of lactate and acetate removal on the microbiota of French fresh pork sausages. Food Microbiol. 2018, 76, 328-336. [CrossRef]

36. Peleg, M. The Hurdle Technology Metaphor Revisited. Food Eng. Rev. 2020, 12, 309-320. [CrossRef]

37. Frank, D.; Zhang, Y.; Li, Y.; Luo, X.; Chen, X.; Kaur, M.; Mellor, G.; Stark, J.; Hughes, J. Shelf life extension of vacuum packaged chilled beef in the Chinese supply chain. A feasibility study. Meat Sci. 2019, 153, 135-143. [CrossRef]

38. Habib, I.; Coles, J.; Fallows, M.; Goodchild, S. Human campylobacteriosis related to cross-contamination during handling of raw chicken meat: Application of quantitative risk assessment to guide intervention scenarios analysis in the Australian context. Int. J. Food Microbiol. 2020, 332, 108775. [CrossRef]

39. Grispoldi, L.; Karama, M.; Hadjicharalambous, C.; Stefani, F.; Ventura, G.; Ceccarelli, M.; Revoltella, M.; Sechi, P.; Crotti, C.; D'Innocenzo, A.; et al. Bovine lymph nodes as a source of Escherichia coli contamination of the meat. Int. J. Food Microbiol. 2020, 331, 108715. [CrossRef] [PubMed]

40. Huang, L.; Zeng, X.; Sun, Z.; Wu, A.; He, J.; Dang, Y.; Pan, D. Production of a safe cured meat with low residual nitrite using nitrite substitutes. Meat Sci. 2020, 162, 108027. [CrossRef] [PubMed]

41. Hashem, A.; Tabassum, B.; Fathi Abd_Allah, E. Bacillus subtilis: A plant-growth promoting rhizobacterium that also impacts biotic stress. Saudi J. Biol. Sci. 2019, 26, 1291-1297. [CrossRef] [PubMed]

42. Kim, D.H.; Cho, W.I.; Lee, S.J. Fault tree analysis as a quantitative hazard analysis with a novel method for estimating the fault probability of microbial contamination: A model food case study. Food Control 2020, 110, 107019. [CrossRef]

43. ISO 7218; Microbiology of Food and Animal Feeding Stuffs-General Requirements and Guidance for Microbiological Examinations. ISO: Geneva, Switzerland, 2007.

44. Hunt, M.; King, A. Meat Color Measurement Guidelines; American Meat Science Association: Savoy, IL, USA, 2012. 